\title{
Variability of soil physical indicators imposed by beech and hornbeam individual trees in a local scale
}

\author{
YAHYA KOOCH ${ }^{1, \vartheta}$, SEYED MOHSEN HOSSEINI ${ }^{1}$, SEYED MOHAMMAD HOJJATI ${ }^{2}$, ASGHAR FALLAH ${ }^{2}$ \\ ${ }^{1}$ Department of Forestry, Faculty of Natural Resources \& Marine Sciences, Tarbiat Modares University, 46417-76489, Noor, Mazandaran, Iran. \\ Tel: +98-122-6253101 (-3), Fax: +98-122-6253499, `email: yahya.kooch@modares.ac.ir \\ ${ }^{2}$ Department of Forestry, University of Natural Resources and Agriculture Sciences of Sari, Mazandaran, Iran.
}

Manuscript received: 25 March 2013. Revision accepted: 26 April 2013.

\begin{abstract}
Kooch Y, SM Hosseini, Hojjati SM, Fallah A. 2013. Variability of soil physical indicators imposed by beech and hornbeam individual trees in a local scale. Biodiversitas 14: 25-30. The objective of our study was to determine if soil physical indicators could be related to the influence of the individual trees in stands of mixed species growing on steep slopes in the Hyrcanian forests of Iran. Research was conducted in a forest dominated by beech (Fagus orientalis Lipsky) and hornbeam (Carpinus betulus L.) interspread with the other deciduous tree species. Due to, twenty hectare areas of Experimental Forest Station of Tarbiat Modares University was considered in northern Iran. The positions of trees with diameter at breast height more than $45 \mathrm{~cm}$ were recorded by Geographical Position System (GPS). Three single-trees (trees with canopy cover separated from other trees and covered distinguished space) considered for soil sampling from every tree species and diameter class as three replications. All of soil samples were excavated in north aspect and at the nearest point to tree collar for more precision. Soil samples were taken at $0-15,15-30$ and $30-45 \mathrm{~cm}$ depths using auger soil sampler with $81 \mathrm{~cm}^{2}$ cross section. The result of this research showed that bulk density was significantly greater under beech than under hornbeam. This character tends to be less in $0-15 \mathrm{~cm}$ depth than in $15-30 \mathrm{~cm}$ and $30-45 \mathrm{~cm}$ depths. Variable amounts of this character were found among diameter classes of beech and hornbeam also. Silt and clay were significantly greater under hornbeam than under beech. Moisture was significantly higher under beech than under hornbeam, whereas soil depths and diameter classes did not show any significant difference. Current research has shown that the influence of individual trees with different diameter classes can be detected in forest floors and upper minerals soil layers even under mixed stands in steepy sloping landscapes. This subject should be considered in natural forests management.
\end{abstract}

Key words: Bulk density, Hyrcanian forest, moisture, old trees, soil texture

\section{INTRODUCTION}

Tree-soil interactions and their influence on tree fitness and forest community dynamics are complex. Many current theories on spatial heterogeneity and species diversity of forest communities are based on the premise that species interaction is controlled by competition for resources such as light, water, nutrients (Binkley and Menyailo 2005). Although these resources are largely constrained by the physical environment, the influence of canopy trees on resources can be of significant importance in forest ecosystem dynamics. This biotic control over resources has received little attention until recently in understanding forest ecosystem dynamics. Several authors have demonstrated the existence of a close interaction between plant and soil (Lovett et al. 2002; Compton et al. 2003; Templer et al. 2005). The evidence above suggests that tree-soil feedbacks need to be incorporated into the concept of species diversity and spatial heterogeneity in forest ecosystems in order to gain more insight in long-term forest dynamics. The soil under the influence of a forest develops properties that vary spatially with relation to the location of the trees. This variation in soil properties is frequently reflected in the distribution of the various species of the ground flora. The amelioration or degradation of the forest soil takes place with each tree as a center of influence (Kooch et al. 2011). Individual species are an important control on soil properties such as structure, water availability, and biota, as well as nutrient cycling. Tree species may influence soil nutrient cycling directly, via nutrient uptake (Turner et al. 1993), litter inputs (Prescott 2002), and induced leaching losses (Compton et al. 2003; Templer et al. 2005), and indirectly, via alteration of microclimate and disturbance regime (Chapin et al. 2002), precipitation chemistry and floral and faunal activities (Smolander and Kitunen 2002).

Studies of trees grown in monocultures effectively isolate species effects on soils, but may not adequately capture species effects in mixed stands (Rothe and Binkley 2001). Despite continued research into tree species effects on soil nutrient cycles, the generality of these effects remains unknown (Binkley and Menyailo 2005). For example, leaf litter decomposition experiments have shown that mixtures of litter of different species can exhibit additive, neutral, and antagonistic effects on overall decomposition that are not easily predicted from the characteristics of the individual litters alone (Gartner and Cardon 2004). More generally, experimental studies of 
grasslands have shown that species diversity and functional characteristics can impact a range of ecosystem processes that serve as the context for individual species effects on soils (Tilman et al. 2001). Thus, plants can shape long-term patterns of soil and ecosystem development (Jenny 1941) in ways that may affect subsequent interspecific interactions and plant-soil relationships. Old-growth forests of northern Iran provide a unique opportunity to examine tree species-soils relationships in a wide range of mixedspecies ecosystems that developed with minimal anthropogenic disturbance. Northern forests of Iran stretch up to an altitude of $2800 \mathrm{~m}$ asl. and comprise different forest types with 80 species of trees and shrubs. There is $1.9 \times 106$ ha of hardwood forests in the north of Iran, which is called Hyrcanian ecosystem (Hosseini et al. 2007; Rouhi-Moghaddam et al. 2008; Poorbabaei and Poorrostam 2009). The Hyrcanian forests are one of the last remnants of natural deciduous forests in the world (Sagheb Talebi 2000).

Beech (Fagus orientalis Lipsky) is one of the most important elements of forests in the temperate broad-leaf forest biome and represents an outstanding example of the re-colonization and development of terrestrial ecosystems and communities after the last ice age, a process which is still ongoing (Mosadegh 2000; Marvie Mohadjer 2007). In the north of Iran, pure and mixed oriental beech forests cover 17.6 per cent of the surface land area and represent 30 per cent of the standing volume. Beech is the most valuable wood-producing species in the Caspian forests (Resaneh et al. 2001). The beech trees are found in small groups up to $500 \mathrm{~m}$ asl. while individuals have been reported from $110 \mathrm{~m}$ up to $2650 \mathrm{~m}$. At low altitudes, they occur mixed with hornbeam (Carpinus betulus L.) (Marvie
Mohadjer 2007). In spite the important of Hyrcanian forests, but earlier study that has evaluated the effects of dominated individual trees on soil characters at the stand level wasn't considered. The objective of this study is to quantify the effects of beech and hornbeam single tree species on soil physical indicators in an old-growth hardwood forest of Iran that is the first survey in these forests.

\section{MATERIALS AND METHODS}

\section{Site description}

This research was conducted in Experimental Forest Station of Tarbiat Modares University located in a temperate forest of Mazandaran province in the north of Iran, between $36^{\circ} 31^{\prime} 56^{\prime \prime} \mathrm{N}$ and $36^{\circ} 32^{\prime} 11^{\prime \prime} \mathrm{N}$ latitudes and $51^{\circ} 47^{\circ} 49^{\prime \prime} \mathrm{E}$ and $51^{\circ} 47^{\prime}$ '56" E longitudes (Figure 1). The maximum elevation is $1700 \mathrm{~m}$ and the minimum is $100 \mathrm{~m}$. Minimum temperature in December $\left(6.6^{\circ} \mathrm{C}\right)$ and the highest temperature in June $\left(25^{\circ} \mathrm{C}\right)$ are recorded, respectively. Mean annual precipitation of the study area were from 280.4 to $37.4 \mathrm{~mm}$ at the Noushahr city metrological station, which is $10 \mathrm{Km}$ far from the study area. For performing this research, a limited area of reserve parcel (relatively undisturbed) considered that was covered by Fagus orientalis and Carpinus betulus dominant stands. This limitation had an inclination 60-70 percent with northeast exposure at 546-648 m asl. Bedrock is limestonedolomite with silty-clay-loam soil texture. Presence of logged and bare roots of trees is indicating rooting restrictions and soil heavy texture (Kooch et al. 2010).
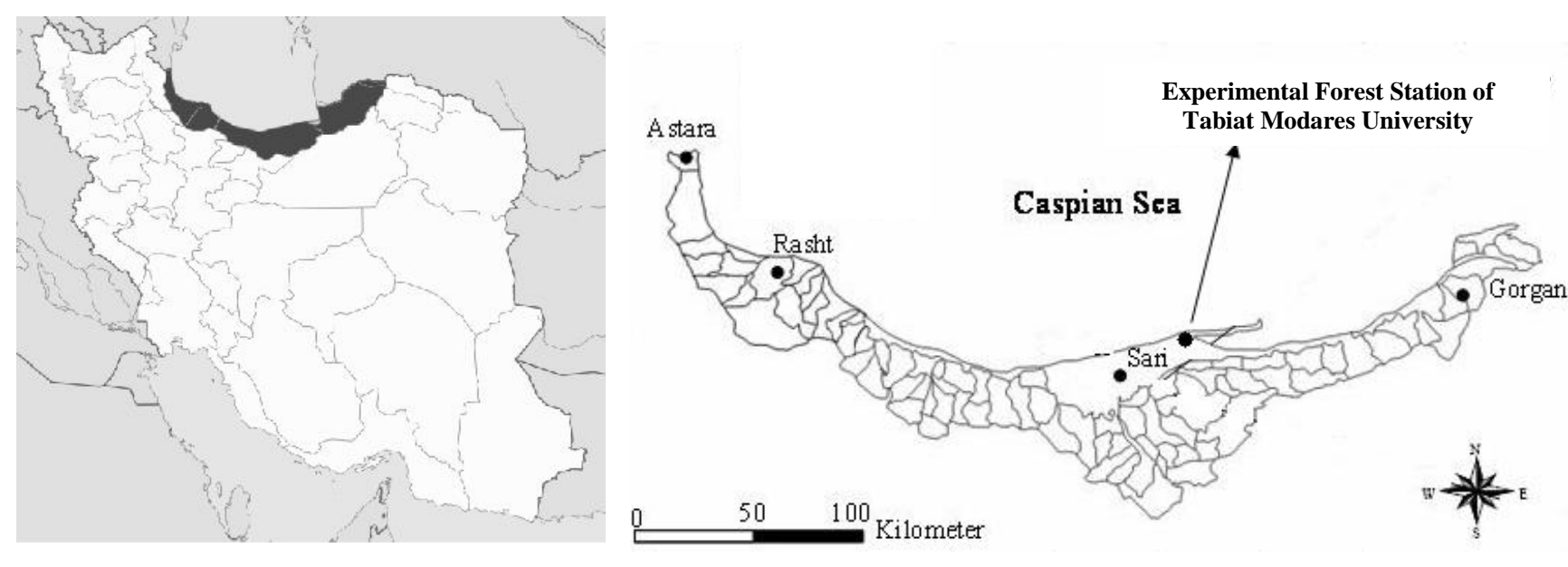

Islamic Republic of Iran

Figure 1. Location of the study site inside the Hyrcanian zone, the Central Caspian region of northern Iran. 


\section{Soil sampling}

Due to examine the influence of forest individual trees on soil physical indicators, twenty hectare areas of Experimental Forest Station of Tarbiat Modares University was considered. The positions of trees with diameter at breast height $(\mathrm{DBH})(1.3 \mathrm{~m})$ more than $45 \mathrm{~cm}$ (Goodburn and Lorimer 1999; Scahrenbroch and Bockheim 2007; Kooch et al. 2011) were recorded by Geographical Position System (GPS). Three single-trees (was defined as trees with canopy cover separated from other trees and covered distinguished space) considered for soil sampling from every tree species and diameter class as three replications. All of soil samples were excavated in north aspect and at the nearest point to tree collar for more precision. Soil samples were taken at $0-15,15-30$ and $30-45 \mathrm{~cm}$ depths using auger soil sampler with $81 \mathrm{~cm}^{2}$ cross section (Kooch et al. 2011).

\section{Laboratory analyses}

For this purpose, large live plant material (root and shoots) and pebbles in each sample were separated by hand and discarded. The air-dried soil samples were sieved (aggregates were crushed to pass through a $2 \mathrm{~mm}$ sieve) to remove roots prior to analysis. Bulk density at air dried moisture content was measured by Plaster (1985) method (clod method). Soil texture was determined by the Bouyoucos hydrometer method (Bouyoucos 1962). Soil moisture was measured by drying soil samples at $105^{\circ} \mathrm{C}$ for 24 hours (Ghazanshahi 1997).

\section{Statistical analyses}

Normality of the variables was checked by KolmogrovSmirnov test and Levene test was used to examine the equality of the variances. Differences between diameter classes and depths in soil properties were tested with twoway analysis (ANOVA) using GLM procedure, with diameter classes $(45-55,55-65,65-75,75-85,85-95,95-$ $105 \mathrm{~cm})$ and depth $(0-15,15-30$ and $30-45 \mathrm{~cm})$ as independent factor. Interactions between independent factors were tested also. Duncan test was used to separate the averages of the dependent variables which were significantly affected by treatment. Independent sample ttest carried out for compare means of soil properties between beech and hornbeam single trees. Significant differences among treatment averages for different parameters were tested at $\mathrm{P} \leq 0.05$. SPSS v. 11.5 software was used for all the statistical analysis.

\section{RESULTS AND DISCUSSION}

Analysis of variance of studied characters is indicating that in relation to beech single trees, the greater amounts of bulk density belong to $45-55 \mathrm{~cm}$ diameter class and the least was detected in $65-75 \mathrm{~cm}$ class (Table 1). This character showed the maximum and minimum in $45-55 \mathrm{~cm}$ and 75 $85 \mathrm{~cm}$ diameter classes, respectively under hornbeam trees (Table 2). Bulk density was significantly greater under beech than under hornbeam (Figure 2). This character tends to be less in $0-15 \mathrm{~cm}$ depth than in $15-30 \mathrm{~cm}$ and $30-45 \mathrm{~cm}$ depths (Tables 1 and 2). Soil texture components showed no significantly difference among diameter classes of beech trees, but the greater amounts of silt content was found in $30-45 \mathrm{~cm}$ depth (Table 1). Under hornbeam, the higher values of silt, clay and lower amounts of sand were considered in 75-85 diameter class (Table 2). Sand content was significantly higher in $0-15 \mathrm{~cm}$, whereas the greater amounts of silt detected in $30-45 \mathrm{~cm}$ depth. Clay amounts did not show any significant difference between depths (Table 2). Silt and clay were significantly greater under hornbeam than under beech (Figure 2). Moisture was significantly higher under beech than under hornbeam (Figure 2), whereas soil depths and diameter classes did not show any significant difference (Tables 1 and 2).

Results of present research are indicating that individual trees can be effective on soil physical indicators. The weight of a tree, combined with the movement of structural roots during windy conditions, can compress soils over centimeter-scales (Chappell et al. 1996). With considering to mountainous position of Hyrcanian forests in Iran and presence of trees with high diameters (old trees), therefore, it is imagined that many of trees are influenced by

Table 1. Mean of soil physical indicators in relation to diameter classes and soil depth in beech site

\begin{tabular}{lllllll}
\hline \multicolumn{2}{l}{ Variable / soil character } & Bulk density $\left(\mathbf{g} / \mathbf{c m}^{\mathbf{3}}\right)$ & Sand $(\boldsymbol{\%})$ & Silt $(\boldsymbol{\%})$ & Clay $(\boldsymbol{\%})$ & Moisture $(\boldsymbol{\%})$ \\
\hline Diameter class $(\mathrm{cm})$ & $45-55$ & $1.13(0.00) \mathrm{a}$ & $33.19(0.59)$ & $37.66(0.31)$ & $29.15(0.28)$ & $40.30(0.27)$ \\
& $55-65$ & $1.11(0.00) \mathrm{bc}$ & $32.04(0.63)$ & $38.72(0.41)$ & $29.23(0.29)$ & $39.54(0.29)$ \\
& $65-75$ & $1.10(0.00) \mathrm{c}$ & $32.11(0.67)$ & $38.61(0.41)$ & $29.27(0.28)$ & $41.82(0.26)$ \\
& $75-85$ & $1.12(0.00) \mathrm{b}$ & $32.00(0.64)$ & $38.72(0.41)$ & $29.27(0.28)$ & $39.93(0.30)$ \\
& $85-95$ & $1.11(0.00) \mathrm{bc}$ & $32.11(0.67)$ & $38.61(0.41)$ & $29.27(0.28)$ & $39.24(0.29)$ \\
Soil depth (cm) & $95-105$ & $1.12(0.00) \mathrm{ab}$ & $33.18(0.58)$ & $37.66(0.31)$ & $29.15(0.28)$ & $39.88(0.30)$ \\
& F-value & $7.60 * *$ & $0.70 \mathrm{~ns}$ & $2.14 \mathrm{~ns}$ & $0.02 \mathrm{~ns}$ & $2.23 \mathrm{~ns}$ \\
& $0-15$ & $1.11(0.00) \mathrm{b}$ & $32.94(0.41)$ & $37.78(0.22) \mathrm{b}$ & $29.27(0.19)$ & $40.21(0.21)$ \\
& $15-30$ & $1.12(0.00) \mathrm{a}$ & $32.71(0.39)$ & $38.07(0.20) \mathrm{b}$ & $29.21(0.19)$ & $39.89(0.22)$ \\
& $30-45$ & $1.12(0.00) \mathrm{a}$ & $31.68(0.48)$ & $39.13(0.31) \mathrm{a}$ & $29.18(0.19)$ & $40.26(0.70)$ \\
& F-value & $10.50 * *$ & $1.90 \mathrm{~ns}$ & $7.86 * *$ & $0.03 \mathrm{~ns}$ & $0.21 \mathrm{~ns}$ \\
\hline
\end{tabular}

Note: ** Different is significant at the 0.01 level. (ns): Non significant differences $(P>0.05)$. Values are the means \pm St. error of the mean (in parenthesis). Within the same column the means followed by different letters are statistically different $(P<0.05)$. 
Table 2. Mean of soil physical indicators in relation to diameter classes and soil depth in hornbeam site

\begin{tabular}{lllllll}
\hline \multicolumn{2}{l}{ Variable / soil character } & Bulk density $\left(\mathbf{g} / \mathbf{c m}^{\mathbf{3}}\right)$ & Sand $(\boldsymbol{\%})$ & Silt $(\boldsymbol{\%})$ & Clay $(\boldsymbol{\%})$ & Moisture $(\boldsymbol{\%})$ \\
\hline Diameter class $(\mathrm{cm})$ & $45-55$ & $1.13(0.00) \mathrm{a}$ & $33.18(0.58) \mathrm{a}$ & $37.26(0.31) \mathrm{c}$ & $29.15(0.28) \mathrm{b}$ & $39.40(0.33)$ \\
& $55-65$ & $1.12(0.00) \mathrm{a}$ & $32.04(0.63) \mathrm{ab}$ & $38.73(0.41) \mathrm{b}$ & $29.23(0.29) \mathrm{b}$ & $39.18(0.30)$ \\
& $65-75$ & $1.09(0.00) \mathrm{b}$ & $30.31(0.66) \mathrm{b}$ & $39.57(0.45) \mathrm{b}$ & $30.11(0.28) \mathrm{b}$ & $39.76(0.28)$ \\
& $75-85$ & $1.05(0.00) \mathrm{c}$ & $25.34(1.89) \mathrm{c}$ & $42.53(1.85) \mathrm{a}$ & $32.07(0.29) \mathrm{a}$ & $39.89(0.32)$ \\
& $85-95$ & $1.11(0.01) \mathrm{ab}$ & $30.27(0.67) \mathrm{b}$ & $39.57(0.45) \mathrm{b}$ & $30.16(0.28) \mathrm{b}$ & $39.41(0.29)$ \\
& $95-105$ & $1.11(0.00) \mathrm{ab}$ & $32.00(0.64) \mathrm{ab}$ & $38.73(0.41) \mathrm{b}$ & $29.27(0.28) \mathrm{b}$ & $39.32(0.27)$ \\
Soil depth (cm) & F-value & $13.89^{* *}$ & $17.08^{* *}$ & $24.79^{* *}$ & $11.10^{* *}$ & $0.70 \mathrm{~ns}$ \\
& $0-15$ & $1.09(0.00) \mathrm{c}$ & $31.92(0.51) \mathrm{a}$ & $37.97(0.21) \mathrm{c}$ & $30.07(0.32)$ & $39.85(0.21)$ \\
& $15-30$ & $1.10(0.00) \mathrm{b}$ & $30.97(0.58) \mathrm{a}$ & $39.02(0.30) \mathrm{b}$ & $29.99(0.31)$ & $39.42(0.19)$ \\
& $30-45$ & $1.11(0.00) \mathrm{a}$ & $28.68(1.23) \mathrm{b}$ & $41.38(0.95) \mathrm{a}$ & $29.93(0.31)$ & $39.21(0.20)$ \\
& F-value & $4.43^{*}$ & $12.34^{* *}$ & $54.87 * *$ & $0.08 \mathrm{~ns}$ & $2.07 \mathrm{~ns}$ \\
\hline
\end{tabular}

Note: ** Different is significant at the 0.01 level. *Different is significant at the 0.05 level. (ns): Non significant differences (P $>0.05)$. Values are the means \pm St. error of the mean (in parenthesis). Within the same column the means followed by different letters are statistically different $(\mathrm{P}<0.05)$.
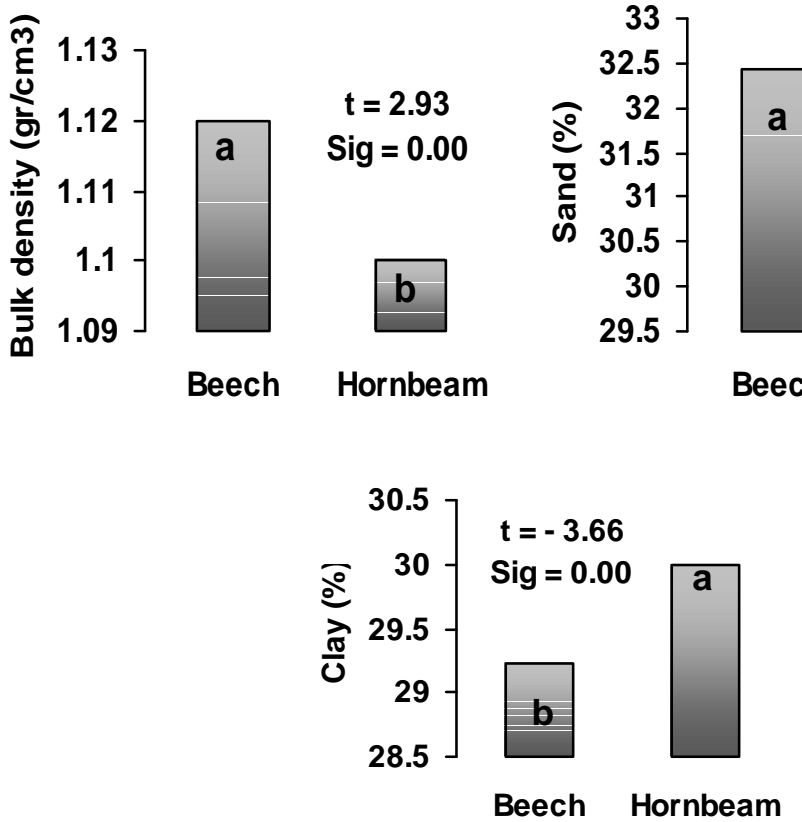
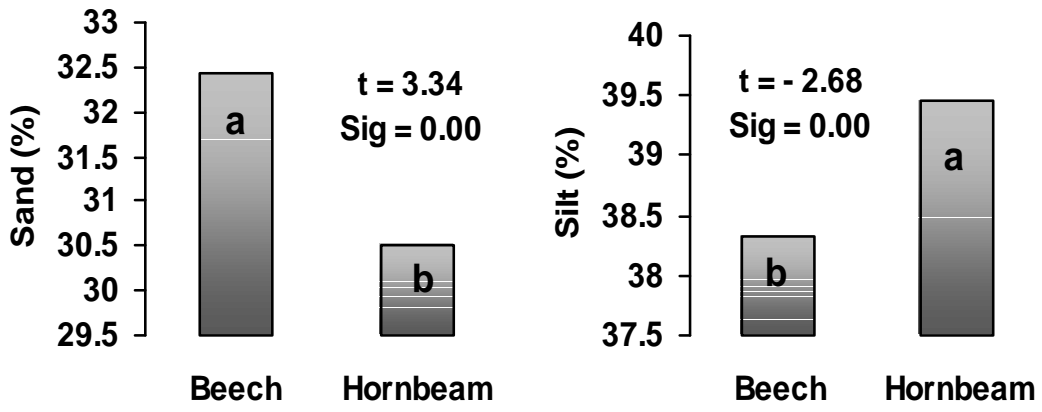

Figure 2. Mean of soil physical indicators in relation to beech and hornbeam individual trees

windthrow event. Old trees in study area (beech and hornbeam) with high diameters and intensive crown covering are similar to sail in front of windthrow, therefore, are more impacted of heavy windthrow. The factors collection together including large crowns and full foliage, rooting form, the higher height and high diameters of these trees making theirs vulnerable to windrthrow (Kooch et al. 2008). Thus, heavy windthrow can be imposed on these trees and are due to theirs movement in small scale that this subject is effective on variability of bulk density. At the millimetre scale, the growth of tree roots can locally increase the density of soil and have a localized impact on bulk density (Blevins et al. 1970; Whalley et al. 2004). Thus, mentioned factors can be effective on variability of bulk density under individual trees. In this research, bulk density increased in soil deeper layers. Both living and decayed roots can create well-connected pores in the topsoil called 'macropores' (Chandler and Chappell 2008). Pay attention to upper soils have more density of fine roots, thus these pores occurred in superficial soils that are due to decreasing of bulk density, finally. Bulk density showed significantly increasing under beech than hornbeam.

Soil acidification due to an increase in the rate of dissolution of soil minerals beneath trees (Augusto et al. 2000), acidic litter-fall (Chappell et al. 2006) or acidic exudates (Chappell et al. 2007) has been shown to reduce soil structural stability. This reduced stability can lead to a reduction in soil porosity. High rates of leaching by infiltrating stem-flow can exacerbate the acidification effect (Augusto et al. 2002). Regarding to low acid under 
beech than hornbeam, thus instability is more considered in soils imposed by beech trees. By this reason, porosity is decreased under beech and bulk density will be increased that is according to obtained result in this research. The soil acidity also affects the presence and abundance of soil fauna, such as earthworms (Neirynck et al. 2000). As earthworm activity creates more stable soil aggregates and adds macro-porosity, reduced abundance would be expected to increase of bulk density. In general, soil $\mathrm{pH}$ detected as the most important effective factor on earthworms abundance (Boettcher and Kalisz 1991; Neirynck et al. 2000). Research results of Kooch et al. (2011) in study area showed that soil pH was significantly less under beech than hornbeam and earthworm's abundance were fewer also. Thus bulk density showed significantly increasing under beech than hornbeam. This result also can be related to more activity of earthworm's population under hornbeam individual trees. The composition of the over story has an impact on soil structure (Read and Walker 1950). Graham and Wood (1991), Graham et al. (1995) have shown that the soil structure and its stability were tree species dependent, probably because of differential effects on worm activity.

Furthermore, wild and domesticated animals use isolated trees for shelter during rainstorms or for shade from intense solar radiation. This congregation of animals, particularly at times when the soil is wet, can compact the soil and thereby increase the bulk density of the soil horizon (Drewry et al. 2000). Regarding to more amounts of moisture under beech than hornbeam, soil compaction was more occurred, thus increasing of bulk density is more considered. Silt and clay were more gathered under hornbeam than beech that can be related to earthworm's greater densities as with creation of macropores they are due to changes in the components of soil texture. Earthworms are able to transferring of smaller components of soil (i.e. clay and silt) to different layers. Beech individual trees with superficial rooting system have more ability for preservation of soil moisture in upper soil. Thus, moisture was significantly higher under beech than under hornbeam, whereas soil depths did not show any significant difference. In total, compared to open areas, the reduced precipitation received beneath tree canopies due to enhanced wet-canopy evaporation (David et al. 2006) combined with greater root abstraction to support transpiration can lead to considerably greater topsoil drying during rain-free periods (Ziemer 1968; Katul et al. 1997).

The study has shown that the influence of individual trees with different diameter classes can be detected in forest floors and upper minerals soil layers even under mixed stands in steepy sloping landscapes. The magnitude of the differences observed depends to some degree on the nature of the forest stand and under story vegetation and on climatically and topographically controlled processes such as litter redistribution and soil creep. In any case, the soil landscape may be viewed as a mosaic, with properties of the individual pedons composing the mosaic reflecting the occurrence and physical characteristics of the tree species present. Differences in substrate properties beneath the crown of juxtaposed tree species may in some cases be large enough to result in short-range variations in soil properties and plant growth (Kooch et al. 2011). Present research was the first survey to quantify the local effect of individual trees on soil physical indicators in Hyrcanian forests of Iran. However, the effect of over story species is strongly influenced by forest management (e.g. low density stands or mixed stands) that, further researches should address this point.

\section{CONCLUSION}

The forest soils can be strongly influenced by tree species. Many studies have addressed the effects of monocultures on forest soil physical, but few have examined the effects of varying ratios of species within stands. In current research, the validity of the concept of "single-tree influence circles" was tested in a forest dominated by beech (Fagus orientalis Lipsky) and hornbeam (Carpinus betulus L.) on steep slopes in the Alborz Mountain, Hyrcanian forest of Iran. In this paper, we presented data on and discussed the effects of individual species trees on soil physical indicators in a single soil map unit in an old-growth northern hardwood forest. Soil bulk density and moisture were significantly greater under beech than under hornbeam. Whereas, silt and clay were significantly greater under hornbeam than under beech. We propose that soil diversity in this oldgrowth northern hardwood forest is substantial and suggest that it be considered in soil survey and forest management.

\section{REFERENCES}

Augusto L, Ranger J, Binkley D, Rothe A. 2002. Impact of several common tree species of European temperate forests on soil fertility. Ann For Sci 59: 233-253.

Binkley D, Menyailo OV. 2005. Gaining insights on the effects of tree species on soils. In: Binkley D, Menyailo OV. (eds). Tree species effects on soils: Implications for global change. Springer, New York.

Blevins RL, Holowaychuk N, Wilding LP. 1970. Micromorphology of soil fabric at tree root-soil interface. Soil Sci Soc Amer J 34: 460-465.

Boettcher SE, Kalisz PJ. 1991. Single-tree influence on earthworms in forest soils in Eastern Kentucky. Soil Sci Soc Amer J 55: 862-865.

Bouyoucos GJ. 1962. Hydrometer method improved for making particle size analysis of soils. Agron J 56: 464-465.

Chandler KR, Chappell NA. 2008. Influence of individual oak (Quercus robur) trees on saturated hydraulic conductivity. For Ecol Manag 256: 1222-1229.

Chapin FSI, Matson PA, Mooney HA. 2002. Principles of terrestrial ecosystem ecology. Springer, New York.

Chappell N, Stobbs A, Ternan L, Williams A. 1996. Localised impact of Sitka Spruce (Picea sitchensis (Bong) Carr.) on soil permeability. Pl Soil 182: 157-169.

Chappell NA, Tych W, Bonell M. 2007. Development of the for SIM model to quantify positive and negative hydrological impacts of tropical reforestation. For Ecol Manag 251: 52-64.

Chappell NA, Vongtanaboon S, Jiang Y, Tangtham N. 2006. Return-flow prediction and buffer designation in two rainforest headwaters. For Ecol Manag 224: 131-146.

Compton JE, Church MR, Larned ST, Hogsett WE. 2003. 2-fixing red alder. Ecosystems 6: 773-785.

David TS, Gash JHC, Valente F, Pereira JS, Ferreira MI, David JS. 2006. Rainfall interception by an isolated evergreen oak tree in a Mediterranean savannah. Hydrol Process 20: 2713-2726. 
Drewry JJ, Littlejohn RP, Paton RJ. 2000. A survey of soil physical properties on sheep and dairy farms in southern New Zealand. New Zealand J Agric Res 43: 251-258.

Gartner TB, Cardon ZG. 2004. Decomposition dynamics in mixed-species leaf litter. Oikos 104: 230-246.

Ghazanshahi J. 1997. Soil and plant analysis. Homa Publ, Tehran.

Goodburn JM, Lorimer CG. 1999. Population structure in old-growth and managed northern hardwoods: an examination of the balanced diameter distribution concept. For Ecol Manag 118: 11-29.

Graham RC, Wood HB. 1991. Morphologic development and clay redistribution in hypsometer soils under Chaparral and Pine. Soil Sci Soc Amer J 55: 1638-1646.

Graham RC, Ervin JO, Wood HB. 1995. Aggregate stability under oak and pine after four decades of soil development. Soil Sci Soc Amer J 59: $1740-1744$

Hosseini SM, Kartoolinejad D, Mirnia SK, Tabibzadeh Z, Akbarinia M, Shayanmehr F. 2007. The effects of Viscum album L. on foliar weight and nutrients content of host trees in Caspian Forest (Iran). Polish J Ecol 55: 579-583.

Jenny H. 1941. Factors of soil formation: a system of quantitative pedology. McGraw-Hill, New York.

Katul G, Todd P, Pataki DE, Kabala ZJ, Oren R. 1997. Soil wate depletion by oak trees and the influence of root water uptake on the moisture content spatial statistics. Water Res Res 33: 611-623.

Kooch Y, Hosseini SM, Akbarinia M. 2008. The ecological effects of pit and mounds created by a windthrow on understory of Hyrcanian forests. J Silva Balcanica 9: 13-28.

Kooch Y, Hosseini SM, Mohammadi J, Hojjati SM. 2010. The effects of gap disturbance on soil chemical and biochemical properties in a mixed beech-hornbeam forest of Iran. Ecologia Balkanica 2: 39-56.

Kooch Y, Hosseini SM, Mohammadi J, Hojjati SM. 2011. Analysis of earthworm's patchy distribution and variability of soil biochemica properties under single-tree influences. Intl J Environ Sci 1: 18131829.

Lovett GM, Weathers KC, Arthur MA. 2002. Control of nitrogen los from forested watersheds by soil carbon: nitrogen ratio and tree species composition. Ecosystems 5: 712-718.

Marvie Mohadjer MR. 2007. Silviculture. Tehran Univ Publ, Tehran.

Mosadegh A. 2000. Silviculture. Tehran Univ Publ, Tehran.

Neirynck J, Mirtcheva S, Sioen G, Lust N. 2000. Impact of Tilia platyphyllos Scop., Fraxinus excelsior L., Acer pseudoplatanus L., Quercus robur L., and Fagus sylvatica L. on earthworm biomass and physico-chemical properties of a loamy topsoil. For Ecol Manag 133 275-286.
Plaster EJ. 1985. Soil science and management. Delmar Publ Inc., Albany, NY

Poorbabaei H, Poorrostam A. 2009. The effect of shelterwood silvicultural method on the plant species diversity in a beech (Fagus orientalis Lipsky) forest in the north of Iran. J For Sci 55: 387-394.

Prescott CE. 2002. The influence of the forest canopy on nutrient cycling. Tree Physiol 22: 1193-1200.

Read RA, Walker LC. 1950. Influence of eastern redcedar on soil in Connecticut pine plantations. J For 23: 337-339.

Resaneh Y, Moshtagh MH, Salehi P. 2001. Quantitative and qualitative study of north forests. In Nation seminar of management and sustainable development of north forests, Ramsar, Iran, August 2000, Jehad-e Agriculture Ministry, Forests and Ranges Organization Press. Vol. 1: 55-79.

Rothe A, Binkley D. 2001. Nutritional interactions in mixed species forests: a synthesis. Canadian J For Res 31: 1855-1870.

Rouhi-Moghaddam E, Hosseini SM, Ebrahimi E, Tabari M, Rahmani A. i. Comparison of growth, nutrition and soil properties of pure stands of Quercus castaneifolia and mixed with Zelkova carpinifolia in the Hyrcanian forests of Iran. For Ecol Manag 255: 1149-1160.

Sagheb Talebi Kh. 2000. Hyrcanian forests (North of Iran), the unique ecosystem in near east region, in proceeding, XXI world congressForests and Society: The role of research, Kuala Lumpur, 13-15 August 2000.

Scahrenbroch BC, Bockheim JG. 2007. Pedodiversity in an old-growth northern hardwood forest in the Huron Mountains, Upper Peninsula, Michigan. Canadian J For Res 37: 1106-1117.

Smolander A, Kitunen V. 2002. Soil microbial activities and characteristics of dissolved organic $\mathrm{C}$ and $\mathrm{N}$ in relation to tree species. Soil Biol Biochem 34: 651-660.

Templer PH, Lovett GM, Weathers KC, Findlay SE, Dawson TE. 2005. Influence of tree species on forest nitrogen retention in the Catskill Mountains, New York, USA. Ecosystems 8: 1-16.

Tilman D, Reich PB, Knops JM, Wedin DA, Mielke T, Lehman C. 2001. Diversity and productivity in a long-term grassland experiment. Science 294: 843-845.

Turner DP, Sollins P, Leuking M, Rudd N. 1993. Availability and uptake of inorganic nitrogen in a mixed old-growth coniferous forest. Pl Soil 148: $163-174$

Whalley WR, Leeds-Harrison PB, Leech PK, Risely B, Bird NRA. 2004. The hydraulic properties of soil at root-soil interface. Soil Sci 169: 90-99.

Ziemer RR 1968. Soil moisture depletion patterns around scattered trees. Research Note PSW-166. US Forest Service, Berkeley. 